\title{
The Sufficiency of Deep Hydrocarbons in the South Caspian Region for Turkey and European Union
}

\author{
Türkiye ve Avrupa Birliği için Güney Hazar Bölgesi'nde Derin \\ Hidrokarbonların Yeterliliği
}

Research Article

İsmail Hakkı Demirel

Hacettepe University, Faculty of Engineering, Department of Geological Engineering, Beytepe, Ankara, Turkey.

\section{A B S TR ACT}

\begin{abstract}
The Caspian Sea region did not appear as an important hydrocarbon province during the Soviet Union. This is because that Soviet Russia has very rich and exploitable oil and gas reserves in areas outside the Caspian region. The Caspian Sea coastal states as Azerbaijan, Turkmenistan and Kazakhstan, after gained their independence, have prioritized assessing the hydrocarbon reserves of the region in line with their governance policies and have started to include external partners in their exploration and development study. In order to develop the long known hydrocarbon assets of the region, the exploration efforts carried out have enabled the discovery of new fields especially in the Azerbaijan sector of the southern Caspian region. In addition, hydrocarbons discovered in the onshore areas of both Kazakhstan and Turkmenistan have made the southern Caspian region the world's major hydrocarbon province. The tectonic evolution and petroleum systems of the hydrocarbon-bearing basins called as the North Caspian, Middle Caspian and South Caspian basins in the Caspian Sea region, differ in terms of both essential elements and processes. The most important differences of the South Caspian Basin are rapid deposition of more than twenty-five km thickness sediment fill resulting from an avalanche type sedimentation and the presence of the young Tertiary hydrocarbon source rocks and reservoirs. Therefore, generation-migration, accumulation and trapping processes of the South Caspian Basin petroleum system are still continuing.
\end{abstract}

Key Words: South Caspian region, deep hydrocarbon occurrence, petroleum system, energy securities, European Union energy demand.

\section{öz}

$\mathrm{H}^{2}$ azar Denizi bölgesi Sovyetler Birliği döneminde önemli bir hidrokarbon provensi olarak öne çıkmamıştır. Bunun nedeni Sovyet Rusya'nın Hazar bölgesi dışında kalan alanlarda petrol ve gaz açısından çok zengin işletilebilir rezervlere sahip olmasıdır. Bugün Hazar Denizi kıyı devletlerinden bağımsızlığını kazanan Azerbaycan, Türkmenistan ve Kazakistan kendi yönetim politikaları doğrultusunda bölgenin hidrokarbon rezervlerini değerlendirmeye öncelik vermişler ve arama-geliştirme çalışmalarına dış ortakları da dahil etmeye başlamışlardır. Bölgenin uzun zamandır bilinen hidrokarbon varlıklarının geliştirilmesine yönelik olarak, özelikle Güney Hazar Bölgesi'nde Azerbaycan sektöründe, yürütülen arama çalışmaları yeni sahaların keşfedilmesini sağlamıştır. Ayrıca hem Kazakistan'ın ve hem de Türkmenistan'ın karasal alanlarında yapılan hidrokarbon keşifleri de özellikle Güney Hazar Bölgesinin dünyanın önemli hidrokarbon provensi haline gelmesini sağlamıştır. Kuzey Hazar, Orta Hazar ve Güney Hazar Basenleri diye üçe ayrılan Hazar Denizi bölgesinde hidrokarbonların oluştuğu basenlerin tektonik evrimi ve petrol sistemleri hem esas elemanlar ve hem de süreçler açısından farklılıklar göstermektedir. En önemli farklılık, Güney Hazar Baseni'nin çabuk depolanma ve çığ sedimantasyon sonucu 25 km kalınlığa ulaşan sediman dolgusu ve hidrokarbonların kaynak kayaç ve rezervuarlarının genç Tersiyer birimleri olmasıdır. Dolayısıyla Güney Hazar Baseni petrol sistemi süreçleri halen devam etmektedir.

Anahtar Kelimeler: Güney Hazar bölgesi, derin hidrokarbon oluşumu, petrol sistemi, enerji güvenliği, Avrupa Birliği enerji talebi.

Article History: Received: Feb 10, 2018; Revised: Feb 16, 2018; Accepted: Sep 3, 2018; Available Online: Oct 4, 2018.

Dol: 10.15671/HJBC.2018.250

Correspondence to: İ.H. Demirel, Hacettepe Uni., Fact. of Eng., Department of Geological Engineering, Beytepe, Ankara, Turkey. 


\section{INTRODUCTION}

The South Caspian basin covers an area about $207.000 \mathrm{~km}^{2}$ and is limited by the Lesser Caucasus (Azerbaijan) in the northeast, Elburz Fold belt (Iran) in the southwest and Kopet-Dag Anticlinorium (Turkmenistan) in the east (Figure 1). The basin sediment thickness is over $4.500 \mathrm{~m}$ thick and in the central basin area, the depth of basement is about $25 \mathrm{~km}$ [1].

There are two hydrocarbon source rock units in the South Caspian Basin: The deep water black shales of the Oligocene-Lower Miocene Maykop Series and deep water, anoxic shales of the Middle Miocene Diatom Formation [1]. The Oligocene-Lower Miocene Maykop units found in shallow depths are the main hydrocarbon source rocks in the South Caspian Basin. Howevera, in the deeper part of the basin, the younger MiddleUpper Miocene Diatom Formation also have source rock characteristics. Total Organic Carbon values of these two source rock units are about $2 \%$ (in weight) and main types organic matter are Type-I and Type-II kerogen [2]. Because of this feature, the deep areas of the South Caspian Sea have become potential hydrocarbon bearing zones. However, as indicated by the recent geochemical data obtained by western companies, hydrocarbons generated from each of the stratigraphic units contains a special biomarker community [1]. Some aspects of hydrocarbon charge within the Azeri portion of the South Caspian basin was studied by Katz et al. [4]. The Energy Information Administration's report [5] outlined the potential oil and gas potential in the Caspian Sea area and re-assessed the latest state of the world's leading oil and gas fields in the light of recent published research.

The main objective of this review, based on the available published scientific data, is to reveal the hydrocarbon potential of the region regarding the petroleum system logic. Hence, this data has been re-evaluated and re-interpreted by the author in terms of petroleum system logic.

\section{Hydrocarbon Potential of the South Caspian Region}

The petroleum systems four economically and strategically important basins of Russia contain hydrocarbon source rocks spanning over 1000 million years. From Precambrian to Tertiary

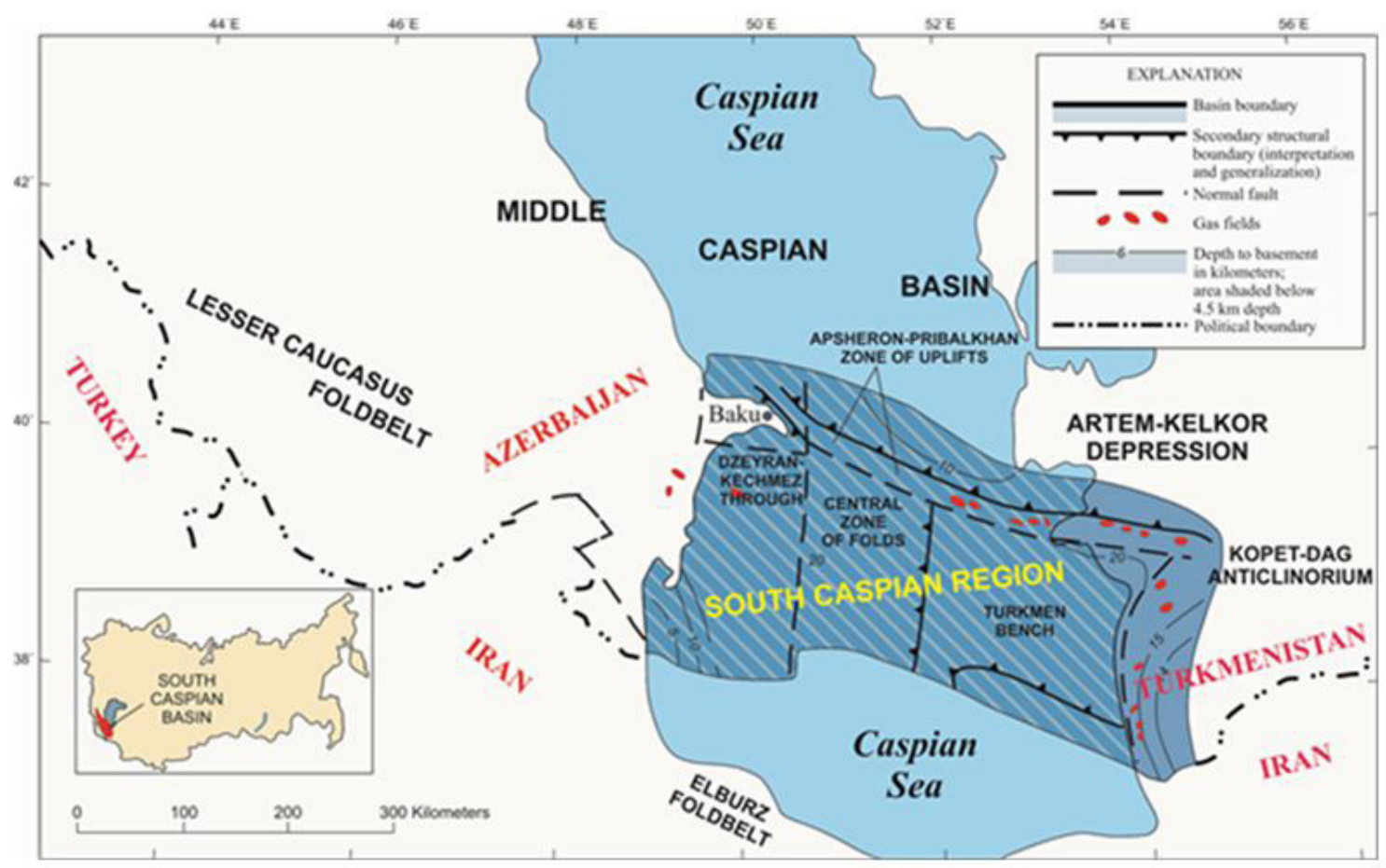

Figure 1. Location map, gas fields, political boundaries of South Caspian Region (after Dyman et al., 2000). 
these basins are Precambrian-Cambrian Siberian Platform, Late Devonian Timan-Pechora Basin, Upper Jurassic Western Siberian Basin which contains $47 \%$ of the total crude oil and $77 \%$ of the natural gas reserves corresponding to total hydrocarbon reserves of the Commonwealth of Independent States and Tertiary North Sakhalin Basin [6]. Russia has become an important actor in energy markets, because of the known large hydrocarbon reserves in these bases.

In the former Soviet Union, the extending area of deep basins, which have a sediment thickness of 15,000 feet $(4,672 \mathrm{~m})$, covers a larger area of 5 million $\mathrm{mi}^{2}$ (3.9 million $\mathrm{km}^{2}$ ) [1]. Some of these basins include deeply explored oil and gas fields. But some basins have not yet been drilled deeply. For determination their geological characteristics and deep hydrocarbon richness, six deep basins, Dnieper Donets, Vilvuy, Northern Caspian, Central Caspian, Southern Caspian and Amu Darya basins were chosen [1]. In this review, only the South Caspian Basin was evaluated.

In the South Caspian Basin, a total of twentytwo oil and gas accumulations were discovered at depths greater than $4.5 \mathrm{~km}$ [7]. The overloaded pressure and plastic behavior of shales are the most important problem encountered during deep drilling work. Since the sandstones of the Production Series are highly porous and permeable, the development of deep basins, is economically feasible. However, towards the east and south, the grain size of the reservoir rocks decreases and the clay content increases. This results in lower reservoir rock quality. It is believed that both the oil and gas reserves are in very high quantities in deep areas of the South Caspian Basin [8], It is necessary that the essential elements and processes of the petroleum systems of the region should be verified controlled by recent advanced data.

Extremely important findings in the reevaluation of the components of the petroleum system of the South Caspian Basin were presented in [4]. Because the samples used in most of the previous studies were both over-degraded and evaluated separately from the geological content. In order to overcome these problems, over 300 samples from eight different localities were collected. The results confirm that the Maykop Unit is a hydrocarbon source rock. Despite the Maykop unit's thickness exceeding $1000 \mathrm{~m}$, net hydrocarbon generating source rock interval is probably about $10 \%$ of the total stratigraphic thickness of this Unit. Organic matter-rich part of Maykop Units does not only constitute oil, but also has a gas-generating potential [4]. Despite the presence of the significant number of wellpreserved samples of the Diatom Unit, unlike what is known, the hydrocarbon generating capacity of the Diatom Units are not proved. According to [4] the following conclusions drawn: The geochemical differences of the hydrocarbon accumulations which were derived from the Maykop Unit are mainly related to their alteration history and geochemical results obtained from gas samples also indicate that hydrocarbons were accumulated through vertical migration. Thermal maturation models are spatially limited to the production parts and verify the necessity of vertical migration. Along with that the lateral migration is also effective in hydrocarbon accumulation in the region. The burial history diagram shows that the generation of hydrocarbons started in Pliocene and Pleistocene times and this process is still going on. Most of the analyzed gas samples imply a mixture of biogenic and thermogenic gases. The common result of this study is; considering the hydrocarbon discharge, the hydrocarbon exploration studies should not be limited to the work of testing the oil system of the Production Series of Maykop Unit of the South Caspian Basin [4].

The hydrocarbon potential of the whole Caspian region have described as four regions extending an area of $760,000 \mathrm{~km}^{2}$ with 50 billion tons of petroleum equivalents in marine areas [9]: These regions are the South Caspian, Central Caspian, Northern Ustyurt and North Caspian. In addition, they have defined six different fields including oil and gas reserves in the Caspian Basin. The hydrocarbon presence in the western continental slope of the South Caspian deep sea basins is about 300,000 tons of crude oil equivalent $/ \mathrm{km}^{2}$. In deep parts of the basin, the hydrocarbon intensity is 100 thousand tons of oil equivalent $/ \mathrm{km}^{2}$. However, this hydrocarbon 
concentration may increase with maintaining the future exploration studies. According to [9], the amount of hydrocarbons in continental and marine areas of the Caspian region is equivalent to 38 and 65 billion tons of oil, respectively. For this reason, near future exploration studies should plan in open marine areas. When compared to Russian part (17 billion tons), Turkmenistan (11 billion tons) and Iran part (7 billion tons) in the South Caspian region, the conventional hydrocarbon reserves in Azerbaijan (27 billion tons of oil equivalents) and Kazakhstan (41 billion tons of oil equivalents) are very high [9].

The hydrocarbon accumulations in Azerbaijan, Iran and Turkmenistan parts of South Caspian region were identified as the Oligocene-Miocene Maykop/ Diatom total petroleum system by [10]. In addition to these source rocks, the Jurassic and Cretaceous carbonates, Eocene shales and Pliocene mudstones deposited in western Turkmenistan display hydrocarbon source rock characteristics as secondary significant potential. The significant hydrocarbon reserves of the region found at 2500-3000 $\mathrm{m}$ depths of Pliocene shallow marine, deltaic and lacustrine sediments. A total of 620 oil and gas fields were discovered in reservoirs ranging from Miocene to Quaternary. The Middle Pliocene rocks should be the main target of the future exploration studies [10]. The most noteworthy part of this work is that deeper depositional system of the South Caspian Basin is unusual in many ways depending on a number of reasons (10).

-Sedimentation rate is extremely high (about $4.5 \mathrm{~km} / \mathrm{my}$.),

-The thicknesses of the sediment fill in the basin is more than $20 \mathrm{~km}$ ( $5 \mathrm{~km}$ in Pliocene)

-Low compaction ratio,

-Low geothermal gradient $\left(1.5^{\circ} \mathrm{C} / 100 \mathrm{~m}\right)$, and

-high pressure values in the central and southeastern parts of the basin [11].

As seen from these parameters, trap formation and preservation process of generated hydrocarbons in the South Caspian petroleum system still continues. Consequently, the porosity and permeability properties required for a hydrocarbon reservoir quality have to maintain at depths as large as $12 \mathrm{~km}$.
Stratigraphic and geochemical features of the Oligocene-Miocene Maykop series and effects of their geochemical changes on the paleogeography of the eastern region of Azerbaijan were investigated by [12]. They suggest that the Maykop Unit be divided into three members based on both lithological and biostratigraphical data. Early Oligocene strata have widely higher TOC values, more negative $15 \mathrm{~N}_{\text {tot }}$ values, more positive $13 C_{\text {org }}$ values and higher radioactivity properties than the Late Oligocene rocks. The results show that the geochemical characteristics of the Maykop series have changed locally and at the same time the study area has been affected by global sea level fluctuations. They reported that bottom water conditions were half-oxicanoxic during deposition of the Maykop series, but when the abundance of trace metals considered the depositional environment gradually became less anoxic over time. Carbon isotope ratios and relatively lower hydrogen index values indicate that the input of terrestrial organic matter is mostly in Chattian (Middle Member of Maykop). Tectonic setting and sedimentation indicate that the South Caspian Basin in Tethys Ocean probably occurred after the deposition of the Maykop layers during the Middle-Late Miocene [12].

Guliyev et al. [13] is a pioneer study for determination of deeper hydrocarbon potential than those known in the Southern Caspian Basin. Using the deep wells opened in the last decade and after discovering the deep hydrocarbon occurrences of less than $5,000 \mathrm{~m}$ in the South Caspian Basin they have estimated the hydrocarbon accumulations found in waters deeper than $7 \mathrm{~km}$. They have also evaluated the information from the breccia that took place about at $14 \mathrm{~km}$ depths of mud volcanoes. Based on [10], the total sedimentation thickness in the Pliocene and Quaternary times is over $10 \mathrm{~km}$ and therefore the total thickness of sediment deposition in the South Caspian Basin is over $25 \mathrm{~km}$. Although [4] have shown that the Diatom Formation does not have any active source rock potential at shallower depths, Smith-Rouch [10] indicated that the Middle-Upper Miocene Diatom Units at these depths also have a good source rock potential. In addition, hydrocarbon source rock potential was 
determined at some levels of Middle Jurassic and Lower Cretaceous sequences. Undoubtedly, the main reason to prove the existence of active hydrocarbon source rocks at this depth is low geothermal gradient between $1.30^{\circ} \mathrm{C}$ and $1.80^{\circ} \mathrm{C} /$ $100 \mathrm{~m}$.

\section{Hydrocarbon Potential and Strategic Position of the South Caspian Region}

The Energy Information Administration [5] reports general assessment of hydrocarbon resources of the Caspian Region and Uzbekistan. This report estimates the presence of proven and probable 48 billion barrels of crude oil and 292 trillion cubic feet ( 8,2 trillion cubic meter) of natural gas in the Caspian Basin. Of these reserves, almost $75 \%$ of the oil and $67 \%$ of the natural gas reserves are located 100 miles from the coast. The Caspian Sea resources have not been widely used until the disintegration of the Soviet Union. Later, when the coastal states that gained their independence, the region has become attractive to foreign participants to access the valuable hydrocarbon deposits. However, the lack of regional cooperation among the governments and the emergence of local interests in the selection of export options have slowed the assessment of Caspian oil and gas resources. Moreover, the legal status of the Caspian area is still complicate owing to the lack of a defined agreement on whether the mass of water is sea or lake. Thus, despite having significant hydrocarbon potential, the Caspian region comes up a variety of challenges-including the need to transport of oil and natural gas - and to find adequate investment for key projects. The fact that the coastal states have not yet reached a full agreement on what the status of the Caspian Sea will be is, unfortunately, an important problem in assessing the economic assets of the region. For this reason, external companies having technological equipment advantages can only participate to a limited extent in the evaluation and development of the hydrocarbon potential of the region. Accordingly, scientific studies focused on the hydrocarbon potential of the region are quite limited. Much of this work was done by the former Soviet Union and by the coastal states themselves. Therefore, these studies must be re-evaluated. The mineralogical compositions of the Pliocene-Pleistocene lithological units, called the Production Series, and the silica and clay mineral assemblages should be determined very well in shallow marine areas and deep sea areas from west to eastward.

\section{Security and Sustainable Energy Resources Demand of European Union Countries}

Many of EU member states are heavily dependent on a single supplier of natural gas including those who are fully dependent on Russia. This dependence leaves vulnerable against to the interruptions of the energy resources demand of the European Union countries. Indeed, a dispute in 2009 between Russia and Ukraine has caused serious problems in many European countries. In response to these concerns, in May 2014, the European Commission published the Energy Security Strategy. Russia, on the other hand, exports about $71 \%$ of its annual gas production to Europe and the two most important customers are Germany and Italy.

In order to minimize political risks and create reliable, sustainable new energy markets, the assessment of South Caspian Basin hydrocarbon resources as a new option is on the agenda of the EU. [14], who views this project is unlikely to meet expectations, has begun discussing the project of transferring Southern Caspian oil and gas resources for transportation to Europe via Turkey (TANAP) (Figure 2).

Sofianos [14] put forward his assumptions in his speech titled "Demolition of European Gas Supply Mitigation" as the targets of the TANAP project are conjectural. He also talks about half of Europe's gas supply is imported from Russia (2012: $139.9 \mathrm{bcm}$ gas) and if all the plans come true, only 10 billion bcm of gas can come from the Shah Deniz-II project to Europe after 2019. As China emerges as the third largest gas user in the world in 2013. China and other South Asian states will try to supply more gas from the Caspian region. Meanwhile the shale gas boom in the United States would be a new alternative to Europe's gas exports. Outside the Arab-Muslim domain, Sofianos [14] evaluates that recent developments in gas reserves in the exclusive economic zones of Israel and the Greek Cypriot Administration, indicate large scale hydrocarbon sources, and 
therefore this region may also be a new energy supply market for the EU. At the end of the presentation, Sofianos [14] released a glimpse of his mouth, stating that TAP-TANAP pipelines, the East Mediterranean Corridor, floating LNG stations (FSRU), Gas Interconnection (IGB, IGI) could contribute to the strengthening of Greece's geopolitical role. Unlike Sofianos [14], Niftiyev [15] says that the annual oil and gas production capacity of Azerbaijan can be transferred to Europe by the Trans-Anatolian Pipeline (TANAP) and Trans Adriatic Pipeline (TAP) projects (Figure 2).

Turkey needs safe and continuous supply of energy resources because of its growing population, developing economy and insufficient conventional hydrocarbon assets in its onshore areas. For these reasons, Turkey appears as a partner with a certain share in some of the projects carried out in the southern Caspian region. At the same time, Turkey is the most suitable transit country for Central Asian energy resources to be transported to other energy markets, especially to Europe. Therefore, Turkey which has a high interest to the region, will be involved in hydrocarbon exploration and development studies and planned pipeline projects from the southern Caspian Sea.

Because of the political instabilities in the Middle East, Caspian region has become an important oil and gas province for energy security policy of European Union countries. In this respect, for EU member states, Turkey is an important energy distribution center or a corridor country in the Mediterranean region. Many export routes for Caspian oil and gas will increase the energy security not only the consumers' but producers and transit states. The decision to choose the most appropriate transit route also reflects serious competition for the strategic interests and economic benefits of the states. Therefore, western pipe-line route from Azerbaijan, Georgia and Turkey to the EU is the foremost project [16]. It is inevitable that the completed main pipeline projects and the ones currently under construction contribute to the EU's energy security. This situation increases the role of Turkey which is an important transit country as an energy hub in Eurasia. It is expected that Turkey should be appreciating this advantageous position in the best way possible.

\section{CONCLUSIONS}

1-Although the total hydrocarbon potential of the South Caspian Basin seems to be fairly lower than the known hydrocarbon reserves of Russia, it is considered that this region is in the top ranks among the world hydrocarbon provinces. The interest of foreign companies to the region is also evidence of its hydrocarbon richness. As given in the text, when the region is evaluated in terms of the petroleum system logic, it is difficult

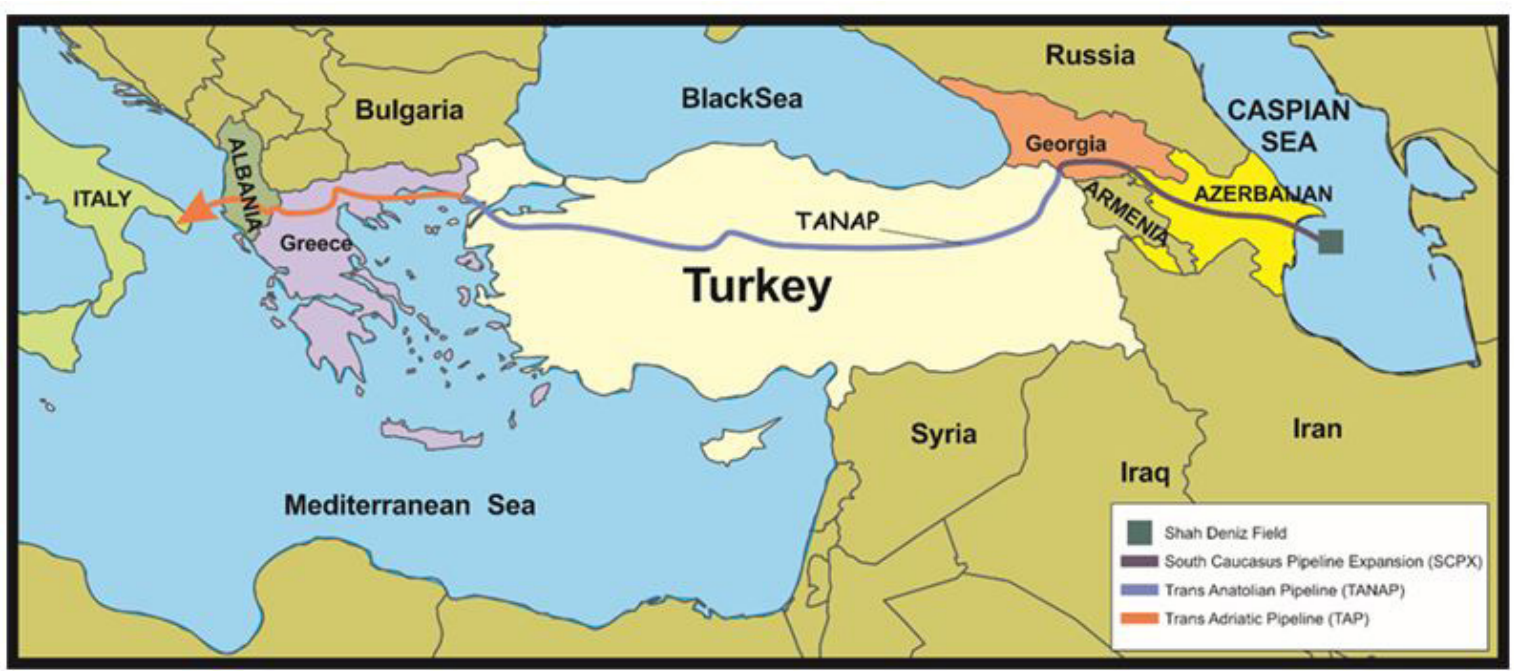

Figure 2. Location map of Trans Anatolian Pipeline and Trans Adriatic Pipeline projects.[18] 
to find satisfying information about key elements (source, reservoir, seal rocks and trapping style) and processes (generation-migrationaccumulation and preservation). In other words, the South Caspian petroleum system is still an ongoing process (Figure 3 ).

2-Before embarking on projects that will invest heavily in the region, the legal rights and boundaries of coastal states in the southern Caspian region must be identified internationally.

3-Many of EU member states are heavily dependent on a single supplier of natural gas including those who are fully dependent on Russia. This dependence leaves vulnerable resulting from the interruptions of the energy resources demand of the EU countries. For example, in 2009, a dispute between Russia and Ukraine has caused serious problems in many European countries. In response to these concerns, in May 2014, the European Commission published the Energy Security Strategy.

4-In the picture drawn in the EU Energy Security Strategy Report [17], European countries are producing and exporting mainly high-tech products. In this way, they were able to maximize the prosperity of their citizens. However, the demand of constantly and secure traditional energy sources of these countries seems to be their most important problems.

5-Could the hydrocarbon potential of the South Caspian Region be an alternative energy supply market for the safe and constantly energy demand for the European Union countries? In order to answer this question correctly, it is necessary to consider the facts set out in the [17]:

-The European Union imports more than half of the energy it consumes. The energy bill paid to foreign suppliers is more than 1 billion per day which is more than the annual import of the European Union (approximately 400 billion in 2013).

-The import dependence of the EU countries is particularly high in crude oil (more than 90\%) and natural gas (66\%),

-Six member states are dependent on Russia as the sole supplier of all gas imports.

-Three of them spend more than a quarter of

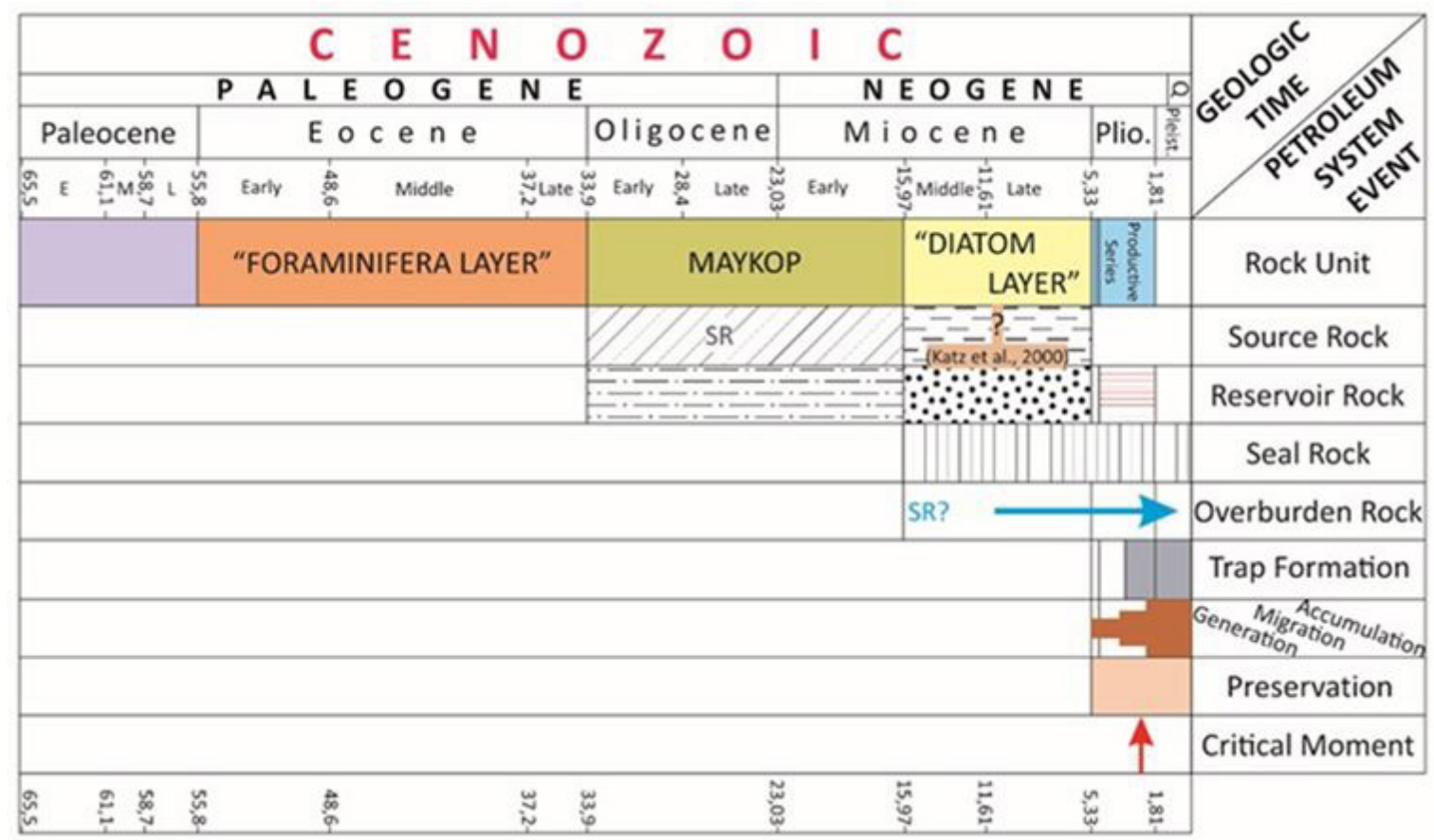

Figure 3. Petroleum system events chart for the South Caspian Basin (compiled from Linda S. Smith Rouch. 2006 and Katz et al., 2000). 
their total energy needs as natural gas.

-In 2013,39\% of the EU's natural gas imports were covered by Russia or $27 \%$ of the EU's gas consumption from Russia.

6-The most urgent energy security issue for the supply of EU energy resources is the dependency to the only external supplier. Although this is particularly true for natural gas, additionally three member states (Estonia, Latvia and Lithuania) are dependent on one suppliers in order to balance their electricity needs.

7-The EU's energy security issue should be addressed within the context of increasing global energy demand. The forecast about this increase will be around $27 \%$ by 2030 with significant changes in energy supply and commercial flows.

However, despite all the positive results mentioned above, determinations of mineralogical composition (silica, feldspar and clay mineral contents) and their relative amounts in bulk rock volume, which are important in calculation of generated and expelled hydrocarbons as well as the net thicknesses of the potential source rock levels, are required. Despite the deep burial of active source rocks, critical point for generation and their preservation time is not certain in the South Caspian Region. It is necessary to evaluate the hydrocarbon potential of the South Caspian region together with the hydrocarbon exploration activities carried out in the Eastern Mediterranean Basin.

\section{Acknowledgements}

The author thanks to Levent Bayram, Dr.Görkem Oskay (Hacettepe University, Department of Geological Engineering) and M. Samet Erdoğan (Karadeniz Technical University, Department of Geological Engineering) for their kindly helps during the preparing of figures.

\section{References}

1. Dyman, T. S., Litinsky, V.A. and Ulmishek, G.F. (2000). Geology and Natural Gas Potential of Deep Sedimentary Basins in the Former Soviet Union. Prepared in cooperation with the U.S. Department ofEnergy-National Energy Technology Laboratory, the Gas Technology Institute, and Advanced Resources International, Chapter C, 29 p.

2. Pigott, N., Smith, M.S., and Simmons, M.D. (1996). Petroleum systems of the South Caspian, AAPG-ASPG Research Symposium Oil and Gas Petroleum Systems in Rapidly Subsiding Basins, October 6-9, 1996: Baku, Azerbaijan, Abstracts, unpaginated.

3. Abrams, M.A., and Narimanov, A.A. (1997). Geochemical evaluation of hydrocarbons and their potential sources in the western South Caspian depression, Republic of Azerbaijan: Marine and Petroleum Geology, v. 14, no. 4, p. 451-468.

4. Katz, B., Richards, D., Long, D., Lawrence, W. (2000). A new look at the components of the petroleum system of the South Caspian Basin. Journal of Petroleum Science and Engineering, v.28, 161-182.

5. Energy Information Administration (EIA). (2013). Overview of oil and natural gas in the Caspian Sea region, Last updated August, 26, 2013. 25 p.

6. Tull, S.J. (1997). The diversity of hydrocarbon habitat in Russia. Petroleum Geoscience, Vol. 3, pp.315-325.

7. Krylov, N.A. (1980). Oil and gas productivity at great depths (Neftegazonosnost bolshikh glubin): Moscow, Nauka, 119 p.

8. Bagir-Zade, F.M., Kerimov, K.M., and Salayev, S.G. (1987). Deep geologic framework and petroleum productivity of the South Caspian mega-depression (Glubinnoye stroeniye I neftegazonosnost YuzhnoKaspiyskoy megavpadiny): Baku, Azerbaijan, Azerbaijanskoye Gosudarstvennoye Izdatelstvo, 304 p.

9. Guliyev, I.S., Levin, L.E., Federov, D.L. (2003). Hydrocarbons potential of the Caspian Region (System Analysis). Baku, "Nafta-Press", 2003, p.120.

10. Smith-Rouch, L.S. (2006). Oligocene-Miocene Maykop/ Diatom Total Petroleum System of the South Caspian Basin Province, Azerbaijan, Iran, and Turkmenistan: U.S. Geological Survey Bulletin 2201-I, 27 p.

11. Guliyev, I., Feizullayev, A., Tagiyev, M. (1997). Isotopicgeochemical characteristics of organic matter source rocks., oil and gas in the South-Caspian basin. In: Lerch, I., Ali-Azdeh, A., Guliyev, I., Bagirov, E., Nadirov, R., Tagiyev, M., Feizullayev, A. Eds.., South Caspian Basin: Stratigraphy, Geochemistry and Risk Analysis, Institute of Geology of Azerbaijan Academy of Sciences Baku.. pp. $90-152$.

12. Hudson, S.M., Johnson, C.L., Efendiyeva, M.A., Rowe,H.D., Feyzullayev, A.A., Aliyev, C.S. (2008). Stratigraphy and geochemical characterization of the Oligocene-Miocene Maykop series: Implications for the paleogeography of Eastern Azerbaijan. Tectonophysics, 451, pp.40-55.

13. Guliyev, I., Aliyeva, E., Huseynov, D., Feyzullayev, A. and P. Mamedov. (2011). Hydrocarbon Potential of Ultra Deep Deposits in the South Caspian Basin. Adapted from oral presentation at AAPG European Region, Annual Conference. Kiev. Ukraine, October 1719, 2010, 66 slides. 
14. Sofianos, N. (2013). Southern Gas Corridor (SGC) Caspian Gas to Europe. Energy Develop-ments in South East Mediterranean Conference-20/21 September, ppt. 24 slides.

15. Niftiyev, E. (2014). Southern Gas Corridor (SGC) Caspian Gas to Europe., ppt. 25 slides.

16. Misiagiewicz, J. (2013). Annales Universitatis Mariae Curie-Sklodowska Lublin-Polonia, Vol. XX, 1, Sectio K, pp.51-67.
17. Energy Security Strategy Reports, (2014). Communication from the commission to the European Parliament and Council. Brussels, 28.5.2014 $\operatorname{COM}(2014) 330$ final, 34 pages.

18. ht tp://www.bp.com/en_az/caspian/ operationsprojects/Shahdeniz/SouthernCorridor.html 